\title{
Editorial Foreword 75.4 (November 2016)
}

\section{Our Cover}

In 1949, the forces of the Republic of China withdrew from the Chinese mainland to Taiwan in the face of advances by the People's Liberation Army. For the next several decades, the small archipelago of Jinmen (Quemoy), held by the Republic of China but located only a few miles off the mainland coast, became a front line of both the Chinese civil war and the global Cold War. Local society became profoundly militarized. This month's cover illustration, "Suspended rocket-shell trap," is drawn from one of many handbooks that were published by the War Zone Administration Commission (Zhandi Zhengwu Weiyuanhui), the highest political authority in Jinmen during this period. These handbooks were distributed to members of the universal militia in which all adult residents of the islands were required to serve. Hundreds of these small booklets-on topics ranging from the conduct of psychological warfare to the recognition of enemy aircraft-can still be found in the offices of the township government of Lieyu (Little Jinmen), ephemera of the links between the villages of Jinmen and larger national and global conflicts. Author Michael Szonyi supplied the figure, which he reproduced from Guiji zhi shezhi yu paichu shouce [Handbook for setting and removal of booby traps], 1971, distributed by Jinmen Fangwei Silingbu [Jinmen Defense Command], p. 31, found in the Lieyu Xianggongsuo Archives.

\section{IN THIS Issue}

The fact that the Journal of Asian Studies strives to serve an organization whose members work on varied countries and are based in varied disciplines means that many issues include articles that touch upon disparate places, deal with diffuse topics, showcase diverse evidence, and employ dissimilar methods. The essays included in any given issue also typically differ from one another in terms of length and sometimes also genre. Even by the standards of the JAS, however, the make-up of this particular issue, which brings to a close three-quarters of a century in the publication's history, stands out as especially variegated.

Consider, for example, the contributions to the "Asia Beyond the Headlines," "Reflections," and "Trends" genres and the Presidential Address with which the issue opens. First comes a topical essay that moves between China and the Middle East and between the Cultural Revolution and the present (Julia LovelL's "From Beijing to Palestine: Zheng Chengzhi’s Journeys from Red Guard Radicalism to Global Islam”); then an adaptation of a keynote lecture by a prominent Sanskritist given at a conference looking back at developments in and debates swirling around South Asian studies in recent decades (Sheldon Pollock’s “Areas, Disciplines, and the Goals of Inquiry”); followed 
by a forum focusing on Amitav Ghosh's The Great Derangement: Climate Change and the Unthinkable (with contributions by Julia Adeney Thomas, a cultural and intellectual historian of Japan; Prasannan Parthasarathi, an economic and environmental historian of South Asia; Roв Linrothe, an art historian with a strong interest in religion; FA-Ti FAn, a specialist in the history of science; and Kenneth Pomeranz, a world historian and China scholar; as well as a response by Amitav GHOSH, who is best known as a novelist but has written important books of nonfiction as well); and then a tour du horizon of visions of political order and imperial ambition in China and other settings circa the middle of the last millennium (Тıмотнy Brook's "Great States," a foray into the history of politics and the history of ideas that is concisely titled but ambitious in scope).

Also bracingly diverse and wide-ranging, though chronologically focused, is this year's "JAS at AAS" forum. Titled "The Cold War in Asia-Antecedents and Fall-out," it is based, per usual, on a panel at the annual meeting, though altered from what took place there in many ways, including via a coda that deals with very recent events. It begins with an opening framing comment by the JAS Managing Editor and organizer of the forum (JENNIFER Munger, "Introduction”). The symposium's centerpiece is an extended consideration American power in the Philippines and neighboring areas before and during the Cold War as seen through the lens of the history of the Philippines (historian ALFRED W. MCCOY'S "Circles of Steel, Castles of Vanity: The Geopolitics of Military Bases on the South China Sea") - a country whose late 2016 diplomatic repositioning is returned to at the end of the forum (via McCoy's "A Rupture in Philippine-U.S. Relations: Geopolitical Implications," written late in October 2016 in the wake of meetings in China that signaled a shift in relations between Beijing and Manila). Commentaries on the central essay follow, by, in turn, a specialist in Indonesian studies and comparative literature (Michael H. Bodden's "Making Circles of Steel and Castles of Vanity Possible: The Cold War in the Longue Durée of 'Modernity"), a political scientist who focuses on South Asia (SHAmpa BisWAS's "Stories of Hegemony: The Political Stakes of the Rise and Decline of US Power"), and a scholar of Ming China and twentieth-century Taiwan (Michael SzonyI's "The Cold War on the Ground: Reflections from Jinmen").

The theme of variation continues into the final part of the issue, the reviews of books dealing with many parts of Asia and written by scholars in many disciplines, and before that the two research articles that close the front of the book. These two stimulating essays take the reader to fourteenth-century Korea via a consideration of letter writing during that era (Hwisang Cho's “The Epistolary Brush: Letter Writing and Power in Chosŏn Korea") and to the land now known as Myanmar in the early to late 1900s through a work of religious history (Thomas Patton's "Buddhist Salvation Armies as Vanguards of the Sāsana: Sorcerer Societies in Twentieth-Century Burma"). 


\title{
Selected Forthcoming Articles in JAS 76.1 (February 2017)
}

\author{
Reflections \\ Chasing the Yellow Demon \\ IAN JOHNSON
}

Research Articles

“Anything Can Be Used to Stimulate Child Development": Early Childhood Education and Development in Indonesia as a Durable Assemblage

Jan Newberry

The Dead in the Land: Encounters with Bodies, Bones, and Ghosts in Northwestern Cambodia

Lisa J. Arensen

The Lingering Effects of Thought Reform: The Khmer Rouge S-21 Prison Personnel Angeliki Andrea Kanavou and Kosal Path

Translation in the Zone of the Dubash: Colonial Mediations of Anuvāda Brian A. Hatcher

Literacy under Authority: The Mongolian Cultural Campaigns

Phillip P. Marzluf

Clandestine Cosmopolitanism: Foreign Literature in the People's Republic of China, 1957-1977

Nicolai Volland

On the Boundaries Between Good and Evil: Constructing Multiple Moralities in China Robert P. Weller and Keping Wu

Political Geography of Empire: Chinese Varieties of Local Government Daniel Koss 